\title{
The Relationship Between Business Environment and Happiness with Corporate Profitability
}

\author{
Mehdi Khazaei ${ }^{1,2}$ \\ ${ }^{1}$ Faculty of Entrepreneurship, University of Tehran, Tehran, Iran \\ ${ }^{2}$ Faculty of Electrical Engineering, Sharif University of Technology, Tehran, Iran
}

Email address:

Mehdi.khazaei@ut.ac.ir

To cite this article:

Mehdi Khazaei. The Relationship Between Business Environment and Happiness with Corporate Profitability. International Journal of Engineering Management. Vol. 5, No. 1, 2021, pp. 12-20. doi: 10.11648/j.ijem.20210501.12

Received: February 19, 2021; Accepted: April 16, 2021; Published: April 29, 2021

\begin{abstract}
Business and investment in any area requires the provision of an appropriate and secure institutional environment. One of the factors that helps to expand businesses and increase corporate profits is the right business environment. Avoiding complicated administrative bureaucracy, lending and credit, proper international trade, and the ease of obtaining the necessary permits will be helpful in this regard. On the other hand, businesses can perform better in a happy and stress-free environment. Happiness is an emotional state characterized by feelings of joy, satisfaction, contentment, and fulfillment. While happiness has many different definitions, it is often described as involving positive emotions and life satisfaction. The purpose of the present study is to investigate the relationship between the business environment and happiness indicators with corporate profitability. For this purpose, 175 top companies in the world from 2013 to 2018 that were profitable among the top 500 companies each year were selected as the statistical population. World Happiness annual report, Doing Business annual reports, and Fortune site were used to collect the data. Also the data analysis was done according to the panel data method using Stata software. The results shows that in general, there is a positive relationship between business environment and happiness indicators corporate profitability.
\end{abstract}

Keywords: Business Environment, Profitability, Happiness

\section{Introduction}

Economic performance is not intrinsically interesting. Noone is concerned in a genuine sense about the level of gross national product last year or about next year's exchange rate. People have no innate interest in the money supply, inflation, growth, inequality, unemployment, and the rest. The stolid greyness of the business pages of our newspapers seems to mirror the fact that economic numbers matter only indirectly. The relevance of economic performance is that it may be a means to an end. That end is not the consumption of beef burgers, nor the accumulation of television sets, nor the vanquishing of some high level of interest rates, but rather the enrichment of mankind's feeling of well-being. Economic things matter only in so far as they make people happier.

Corporate profitability is influenced by various factors such as entrepreneurship, technology, marketing, product, management, finance, and environmental factors including turbulence, heterogeneity, environmental dynamics, competitiveness, and corporate exclusivity (Chorev \& Anderson, [8]). Profitability is closely related to profit but with one key difference. While profit is an absolute amount, profitability is a relative one. It is the metric used to determine the scope of a company's profit in relation to the size of the business. Profitability is a measurement of efficiency and ultimately its success or failure. A further definition of profitability is a business's ability to produce a return on an investment based on its resources in comparison with an alternative investment. Although a company can realize a profit, this does not necessarily mean that the company is profitable (Horton, 2019).

A weak contract and legal environment can increase business costs with the effects of employment, production, investment, productivity, and living standards (Besley, [5]). Characteristics of the business environment are effective and predictive factors for entrepreneurial activities. In dynamic environments with growth, there is a greater desire for entrepreneurial activity, innovation and product development. 
While in static and unchanging environments, entrepreneurial activities and risky investments are less frequent (Zahra, [34]), the favorable business environment leads to increased entrepreneurial activities and consequently to increased employment, Knowledge production, economic growth and poverty reduction. Reforming the National Business Environment Improves Entrepreneurial Activities (Audretsch et al., [2]). The level of public services and infrastructure development in an area is positively correlated with local entrepreneurial activities (Sai Lan et al., [22]).

De Soto [9] considers the reason for underdevelopment and the difference between developing countries and developed countries only because the poor people in these countries have a product but do not have a formal sales document; they have business and property but lack legal personality. De Soto and his colleagues showed that in Peru, setting up a tailor-made workshop required 1231 administrative steps and 289 days. As a result, people prefer to work underground and informal rather than formal registration. In other words, according to De Soto's theory, the barriers of the bureaucratic system in developing countries lead the private sector to an underground, informal and unproductive economy. The business environment is a set of rules that affect the cost of the company. Such as the cost of licenses, formalities, taxes, labor costs, etc. (UNIDO, [31]).

Easterlin [13] was one of the first economists to study statistics over time on the reported level of happiness. His data came from the United States. Easterlin's [12] paper's main objectives were, first, to suggest that individual happiness appears to be the same across poor countries and rich countries, and, second, to argue that economic growth does not raise well-being. Easterlin suggested that we should think of people as getting utility from a comparison of themselves with others close to them: happiness is relative. The modern stress on the benefits of higher total national income is then misplaced, because individuals all move up together. A similar theme is taken up in Hirsch [20] and Scitvosky [28], and still more in Frank [15].

There seems to be a significant relationship between happiness, business environment and corporate performance. In this article, we want to examine this relationship.

\section{Research Background}

Zhang [35] considers firm performance as a function of the characteristics of managers, business characteristics, environmental factors, and the urban population in which the company is located. Contingency theory was introduced by Thompson in 1967, and he knows the key to business in how to achieve its goals in an uncertain environment based on rationality. According to Parsons [25], businesses manage and control their affairs at the three technical, managerial, and institutional levels. These three levels differ in their origin and degree of uncertainty. The underlying assumption in this theory is that in order to achieve rationality and control the activities of the business, the business aims to reduce the impact of uncertainty on the technical core. This policy can only be enforced when the activities related to the supply of product and supply factors are separated from the technical sector, and there is a greater uncertainty over the managerial and institutional levels. The key contingency factors that influence the structure of an organization are uncertainty, complexity, and variability.

According to the Doing Business report, 10 indicators of the business environment affect entrepreneurship and business performance (financial and non-financial). Being wealthy, of course, does not mean being in the right position for business ease, as many high-income countries are still far from their ideal location. In fact, less bureaucratic hurdles, powerful legal institutions, and laws and regulations developed based on successful international trade are factors that play a decisive role in the ease of doing business. Here are two examples of Georgia and Macedonia. Since the first Business Ease Report was released in year 2003, Georgia and Macedonia have had the highest rate of reforms among the countries in the world by applying 47 and 41 amendments to business laws, respectively. The result of the reforms was Georgia's rank 9 and Macedonia's rank 11 in the 2018 report.

\subsection{Business Environment}

Each year, the World Bank assesses 10 indicators for countries in its Ease of Business report. These are 10 indicators: "Starting a business", which covers the process, time, cost and minimum capital needed to start a limited liability company. "Dealing with construction permits", which measures the process, time and cost of completing the administrative process of building construction and quality control and safety mechanisms, "Getting electricity " which measures the process, time and cost of connecting to the electricity grid and ensuring electricity supply and tariff transparency, "Registering property" which measures the process, time and cost of the asset transfer and the quality of the property administration system, "Getting credit" which measures the status of the collateral and the credit information system, "Protecting minority investors" which examines the rights of micro investors in corporate management, "Paying taxes" which reviews payments, timing and compliance with tax laws, "Trading across borders" which measures the time and cost of exporting advantageous goods and importing machinery, "Enforcing Contract" which measures the time and cost of resolving economic disputes and the quality of judicial proceedings, And "Resolving insolvency" which examines the timing, cost, consequences, and rates of economic bankruptcy recovery and the power of the legal framework to deal with bankruptcy. In this report, higher scores and lower ratings mean better economies. Although economies that have the best business laws have different spectra, they have some commonalities, according to the Doing Business. Out of the top 20 ranking countries in 2018, 14 of the high-income countries are members of the Organization for Economic Co-operation and Development, three from Europe and Central Asia, and three from East Asia and Oceania. Also, 18 of the top 20 
economies are from the group of high-income countries (Doing Business, [10]).

There are two general approaches to economic development and entrepreneurship in different countries. The first is privatization and the second is to improve the business environment (Dyck, [11]). Governments can amend their tax laws, amend labor laws, and reduce the number of permits and inspections required for businesses. Unfair regulation and a large bureaucracy encourage bureaucrats and businesses to become corrupt, especially if the probability of punishment is low. In addition, reforming the judiciary in order to strengthen it in punishing corrupt and criminals can reduce the level of corruption and crime (Bah \& Fang, [3]).

The European Foundation's model of organizational excellence presents the quality of business performance as measuring an individual, a group, an organization or a process level in achieving a specific goal. In other words, performance is the measure of the efficiency and effectiveness of a mechanism or process by an organization in achieving its desired results $(\mathrm{Wu},[33])$. The measurement of business performance by financial and non-financial subjective indicators is adequate and this measurement can be used to measure business performance (Sandeep \& Harpreet, [26]). In their research, Sandeep and Harpreet analyze the financial dimensions of sales growth, return on capital and turnover volume and non-financial dimensions of market share, service quality, customer satisfaction, product quality, employee satisfaction, product innovation and process innovation. They have considered. Increasing employees' abilities and capabilities has direct effects on financial outcomes and thus on corporate performance (Becker et al., [4]). Strategic capabilities are important for the successful performance of companies (Simon et al., [29]). But they do not inform organizations how they can quickly and easily restructure their resources at the right time, in the form of dynamic business capabilities. Dynamic business capabilities generally include innovation, information capability and communication capability. Innovation capabilities include product design, new product development, and business process innovation (Camison \& Villar, [7]).

\subsection{Happiness}

The World Happiness Report is published every year. This report examines the situation of different countries in the world in terms of happiness parameters, which include the following (WHR, 2018):

\subsubsection{Freedom}

It is always believed that people could live happier if their society practices freedom, equality and brotherhood. Freedom is considered as having the opportunity to choose and being able to. This means that being free requires the absence of restrictions in economic, political and personal life. Absence of economic and political restrictions can be used to measure differences across nations in their degree of freedom.

\subsubsection{Corruption}

Corruption is generally considered as an important factor which defines the quality of countries' governance. It doesn't have any geographical limits and exists everywhere. As shown by Abed and Gupta (2002), even though corruption is more spread in poor countries, it isn't restricted to specific region or levels of economic development.

\subsubsection{GDP}

Economic growth is one of the main objectives of any economy. High economic growth rates and low economic growth contribute to economic development.

\subsubsection{Infrastructure}

Infrastructure is the backbone of many economic, social and political life activities in societies. Countries that do not care about infrastructure will be affected by the decline of its growth and development.

\subsubsection{Unemployment}

Happiness and work was the subject of various empirical economic studies. Jobs are very important for sustaining individual's living, family and health which are the main elements shaping people's happiness.

\subsubsection{Marital Status}

Generally, healthy and supportive relationships contribute greatly to higher happiness levels. The last world happiness report stated that, in western countries, having a partner has a strong positive impact on individual's happiness.

\subsubsection{Health}

Since long decades many analysis presented the interaction between health and happiness. A good health will make people feel more cheerful and causes a greater contentment in their daily life. However having a bad physical or mental health leads to more restrictions in people's daily activities and causes a pessimistic view of life.

\subsubsection{Education}

Happiness and education are strongly connected. A good education contributes significantly to personal and collective happiness. It is generally admitted that education improves people's lives in many aspects. Education enhances people's lives as higher educational attainment is linked to better career paths and is also believed to enhance outcomes in other life domains, such as health and relationships.

A growing number of companies claim to place a high priority on the wellbeing of their workers - and there is a fast-growing industry of firms selling products related to employee wellbeing. But does investing in employee wellbeing actually lead to higher productivity and are there any tangible benefits to the business bottom line? Experimental evidence such as Oswald et al [24] suggests that the answer is yes. Wright and Staw [32] find a significant and sizeable effect of long term happiness on productivity. More specifically, Boehm and Lyubomirsky [6] preliminarily define a happy person as someone who frequently experiences positive emotions like joy, satisfaction, 
contentment, enthusiasm and interest. Then, by drawing on both longitudinal and experimental studies, they show that people of this kind are more likely to be successful in their careers. Wright and Staw [32] examined the connections between worker affect and supervisors' ratings of workers. Depending on the affect measure, the authors find mixed results. Amabile et al. [1] uncovers evidence that happiness provokes greater creativity. In contrast to our paper's later argument, Sanna et al. [27] suggests that those individuals in a negative mood put forth a high level of effort. Gneezy and Rustichini [17] examine the relationship between monetary compensation and performance. They provide contrasting kinds of evidence. They show that increasing the size of monetary compensation raises performance, but they also find that offering no monetary compensation can be better motivation than offering some. They discuss how to rationalize this finding, and offer several possible explanations. One is based on the notions of intrinsic and extrinsic motivation developed within psychology.

Hans and Tarasofsky [19], Focused on gross domestic product (GDP) and pointed out that gross domestic product
(GDP) was sufficient for the index of social well-being, as well as the measure of economic welfare, which some economists as Nordhaus and Tobin [23], Explained the measures of economic welfare and defined the requirements of growth as any country in net national product. Also pointed out that there is a GDP gap and economic welfare in San Francisco. Richard A. Easterlin et al [14], Proved that there is a contradiction between happiness and income in the long term through his various questionnaires, which included many questions about happiness and satisfaction of life. Happiness from their point of view does not increase with the rising incomes of the country.

Teng Guo, and Lingyi $\mathrm{Hu}$ [30], investigated the relationship between happiness and different economic variables in the United States. Their results showed that individual well-being can be predicted and measured. Authors concluded that there is an inverse relationship between happiness, unemployment and inflation, and this has been proven by many previous studies.

Figure 1 shows correlations between employee wellbeing, employee productivity and firm performance.

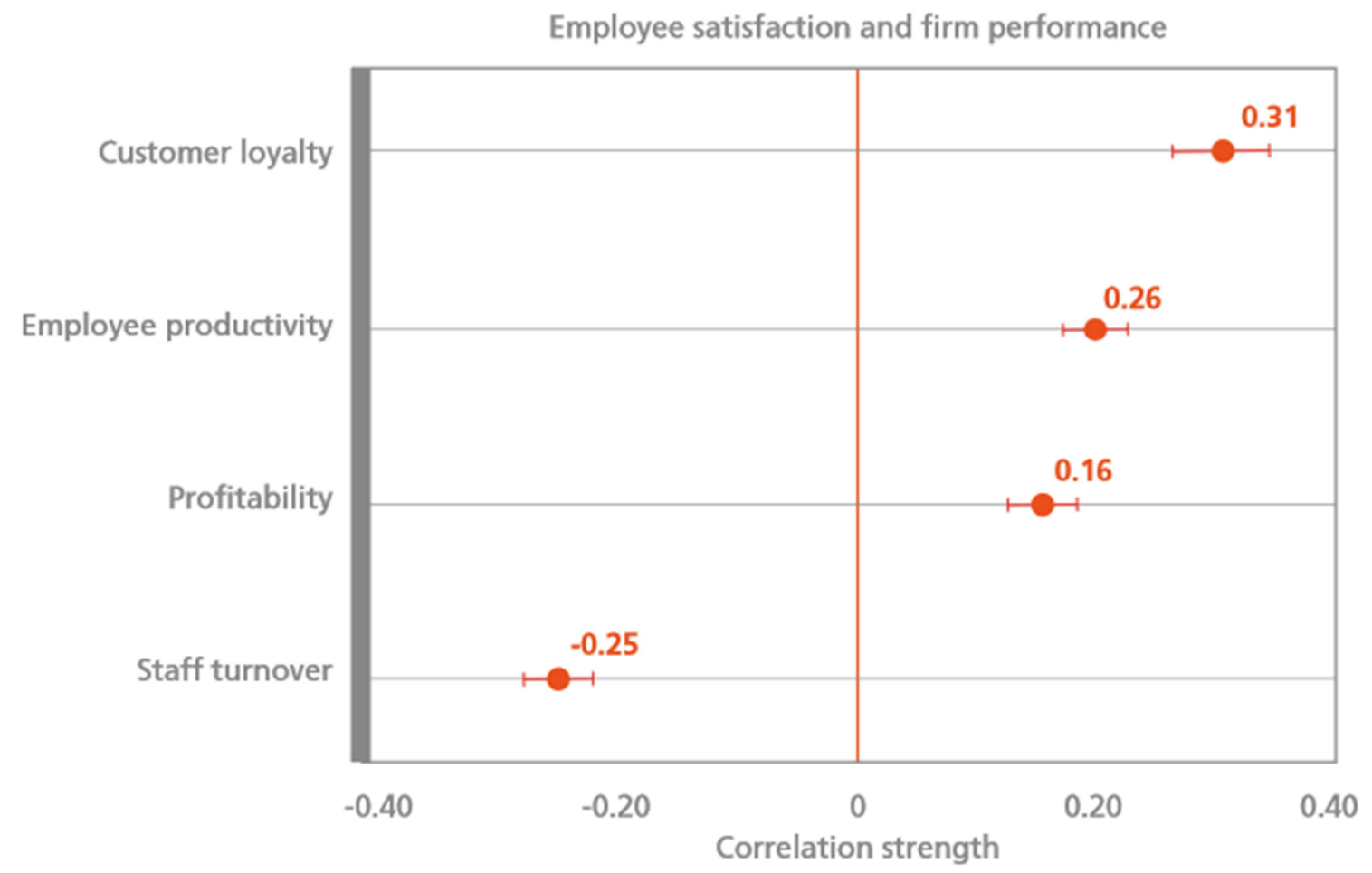

Figure 1. Correlation between employee satisfaction, productivity and firm performance (Gallup client database, 95\% confidence intervals).

Hypothesis 1: The Business environment index has a positive relationship with the corporate profitability.

Hypothesis 2: The Happiness index has a positive relationship with the corporate profitability.

\section{Hypothetical Research Model}

Based on the hypotheses presented, the hypothetical model of the present study is shown in figure 2 .

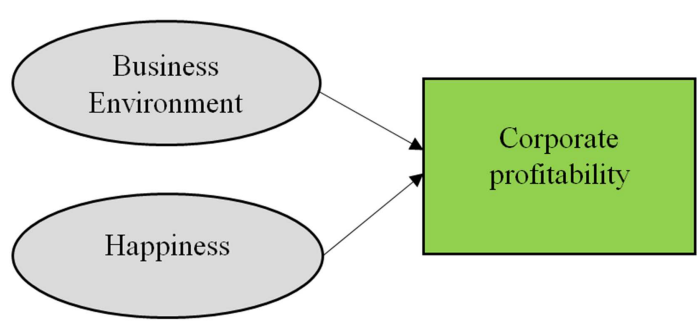

Figure 2. The hypothetical research model. 


\section{Research Method}

This study is practical and in terms of data collection method, this is secondary data. It is also a quantitative research method because it seeks to distribute the characteristics of a statistical population. The research consists of three general stages; firstly, using library studies, reviewing existing texts, models, and related theories, and selecting the appropriate model. In the second step, the data are collected and pre-processed according to the hypotheses and sample size, and in the last step, using panel data modeling approach and using SPSS and Stata software, the collected data were analyzed using econometric methods and data were analyzed. The dependent variable of the research is the Corporate Profitability (CP). The independent variables of the research are Doing Business (DB) and Happiness (H) indicators.

Every year, Fortune site a report on revenue, profitability, industry type, number of employees, and more from the top 500 companies in the world. Given that the dependent variable in this study is the profitability of the top companies and the profitability difference between the top companies and the down companies is high, out of 500 companies, 200 companies that have profitably ranged from 1 to 200 Statistical population is considered. The statistical population of the study is the countries whose company or companies were among the top 200 companies in the world for profitability from 2013 to 2018. In this study, data related to 175 large companies in the world, which belong to 23 countries, have been examine. Data on the dependent variable are extracted from Fortune's annual reports and data on independent variables from the Doing Business Report and World Happiness annual reports between 2013 and 2018.

\subsection{Data Analysis}

Descriptive statistics and inferential statistics were used to analyze the collected data. The descriptive statistics of the graphs, Central indicators (mean) and dispersion (standard deviation) indices and SPSS software is used for this purpose. In the inferential statistics section, since the nature of the data is cross-sectional and time series, the panel data technique is used.

Panel data is a combination of cross-sectional data and time series, meaning that we observe cross-sectional data over time. It is clear that such data have two dimensions, one dimension being related to different units at each specific time point and the other dimension being time. The use of panel data methods over cross-sectional and time series methods has two major advantages: First, it allows the researcher to consider the relationship between variables and even units (companies) over time, and The second advantage is the ability of this method to control the individual effects of companies (as cross-cutting units) that are not observable and measurable.

In statistics, linear regression is a linear model approach between response variables with one or more descriptive variables. Regression is often used to explore the linear relationship model between variables. In this case, it is assumed that one or more descriptive variables whose value is independent of the other variables or under the researcher's control can be effective in predicting the response variable whose value is not dependent on the descriptive variables under the researcher's control. The purpose of regression analysis is to identify the linear model of this relationship.

The general form of the linear K-variable regression model is as follows:

$$
\begin{gathered}
Y_{i}=\beta_{1}+\beta_{2} X_{2 i}+\beta_{3} X_{3 i}+\ldots+\beta_{K} X_{K i}+u_{i} \\
(i=1,2, \ldots, N)
\end{gathered}
$$

Where the $\beta_{1}$ is width of the origin, $\beta_{K}$ is the coefficients of partial angles, $\mathrm{u}$ are the random disruption component (estimation error), $\mathrm{N}$ is the size of the original population, and $\mathrm{i}$ represents the $\mathrm{i}$-th observation. $\mathrm{Y}$ denotes the dependent variable and $\mathrm{X}$ denotes the independent variable. (Gujarati, [18]).

By expanding the main equation we will have:

$$
\begin{aligned}
& Y_{1}=\beta_{1}+\beta_{2} X_{21}+\beta_{3} X_{31}+\ldots+\beta_{K} X_{K 1}+u_{1} \\
& Y_{2}=\beta_{1}+\beta_{2} X_{22}+\beta_{3} X_{32}+\ldots+\beta_{K} X_{K 2}+u_{2} \\
& \vdots \\
& Y_{N}=\beta_{1}+\beta_{2} X_{2 N}+\beta_{3} X_{3 N}+\ldots+\beta_{K} X_{K N}+u_{N} \\
& {\left[\begin{array}{c}
Y_{1} \\
Y_{2} \\
\vdots \\
Y_{N}
\end{array}\right]=\left[\begin{array}{ccccc}
1 & X_{21} & X_{31} & \ldots & X_{K 1} \\
1 & X_{22} & X_{32} & \ldots & X_{K 2} \\
\ldots & \ldots & \ldots & \ldots & \ldots \\
1 & X_{2 N} & X_{3 N} & \ldots & X_{K N}
\end{array}\right]\left[\begin{array}{c}
\beta_{1} \\
\beta_{2} \\
\vdots \\
\beta_{K}
\end{array}\right]+\left[\begin{array}{c}
u_{1} \\
u_{2} \\
\vdots \\
u_{N}
\end{array}\right]} \\
& Y=\quad X \quad \beta+u \\
& \begin{array}{llll}
N \times 1 & N \times K & K \times 1 & N \times 1
\end{array} \\
& Y=X \beta+u
\end{aligned}
$$

If one observes autocorrelation or variance heterogeneity, the generalized least squares (GLS) method can be used to estimate the coefficients. However, using this method requires some guesses about the variance-covariance matrix of the disturbance statements that the use of the variance-covariance matrix of the estimated OLS model as a starting point and the use of iterative methods can be helpful in this regard.

\subsection{Findings}

The minimum, maximum, mean, standard deviation, Kurtosis and skewness of the research variables are listed in Table 1. Because the distribution of the research variables is not normal by logarithmizing the data, their distribution is normalized. It should be noted that due to the large amount of corporate profits, these values are scaled between 0 and 100 to allow for comparison with other variables. For example, 
the highest profit is $\$ 53394$ million, which is scaled to 99.8 .

Table 1. Descriptive indices of the research variables.

\begin{tabular}{lllllll}
\hline Variable & Skewness & Kurtosis & St. Deviation & Mean & Max. \\
\hline CP & 2.827 & 9.632 & 13.656 & 14.775 & 96.8 \\
DB & 2.827 & 0.581 & 7.558 & 76.306 & 84.970 \\
H & -1.002 & 0.36 & 0.716 & 6.567 & 53.310 & 7.650 \\
\hline
\end{tabular}

In order to analyze the data using the panel data method, a number of tests must be performed in the first step to determine the method of analysis. These tests are:

\subsection{Unit Root Test}

Before estimating the model, it is necessary to Durability test all variables used in the research model. Because the ephemeral of the variables causes the problem of false regression. In this study, the Levin, Lin, and Chu (LLC) unit test were used to investigate the variables maneuverability. The basic assumption of the LLC test is the existence of a single root process between sections. Based on the results of Table 2, all the research variables are either at a stable level or in other words zero degree of accumulation.

Table 2. Unit Root Test.

\begin{tabular}{llll}
\hline Var. & Statistic & Prob. & Degree of accumulation \\
\hline $\ln \mathrm{DB}$ & -1142.312 & 0.000 & $\mathrm{I}(0)$ \\
$\ln \mathrm{H}$ & -397.817 & 0.000 & $\mathrm{I}(0)$ \\
\hline
\end{tabular}

\subsubsection{Research Model Analysis}

The purpose of the present study is to investigate the relationship between the business environment and happiness indicators with corporate profitability. This model has the following functional form:

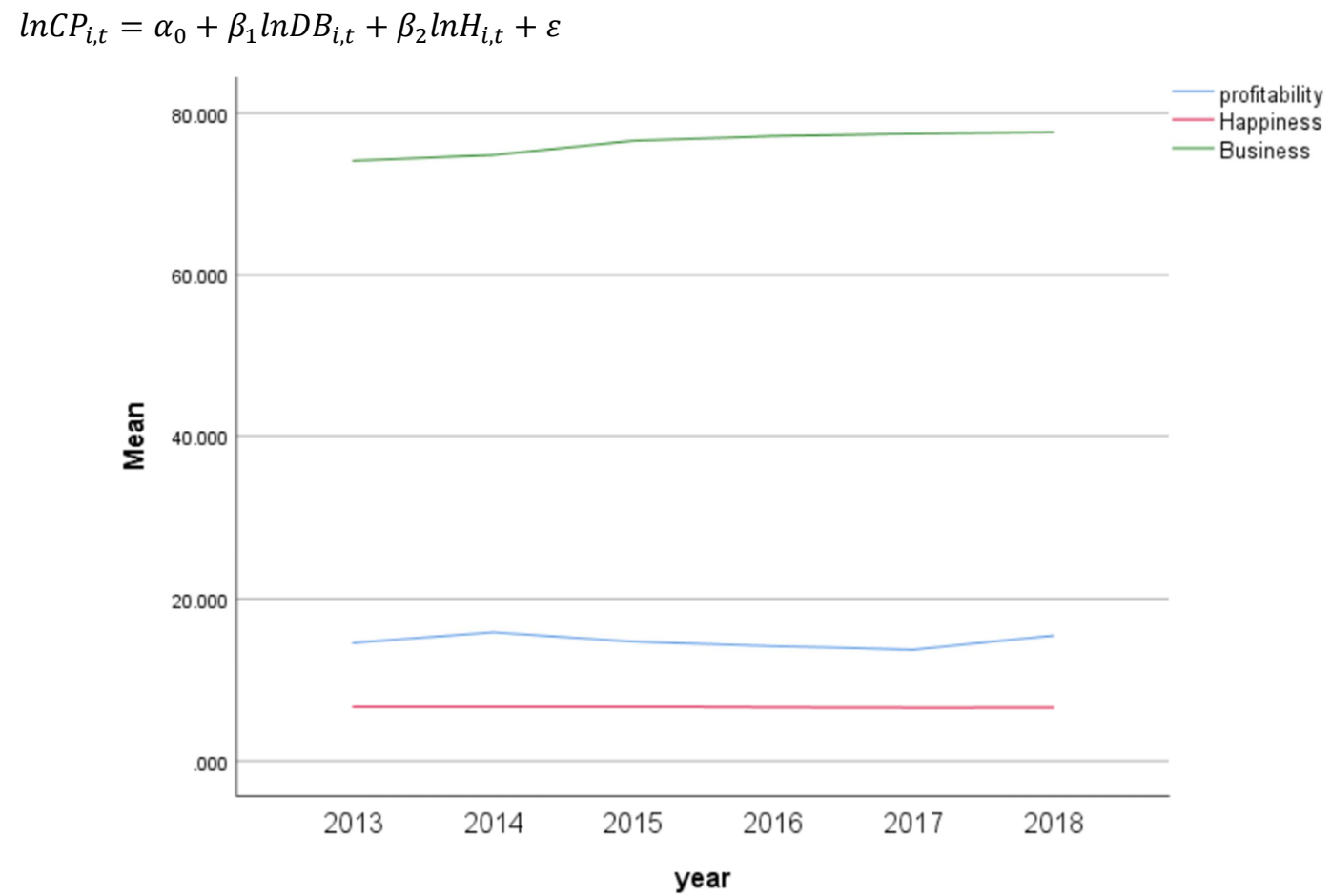

Figure 3. Trend of the mean of the research model variables between 2013-2018.

\subsubsection{F-Limer Test}

In order to investigate the type of model in panel data method, F-Limer test was used. In this test, the null hypothesis of the existence of a pool method is tested against the hypothesis of a panel data method. If the null hypothesis
Where $\alpha_{0}$ is the width of the origin and $\varepsilon$ is the estimated error. In order to estimate the above model, the F-Limer test and then the Hausman test for the type of estimation model should be performed. After confirming the results of these tests, the final model is estimated. 
Table 3. F-Limer fixed effects test for the research model.

\begin{tabular}{llll}
\hline Test & Statistic & d.f. & Prob. \\
\hline F & 23.472 & $(174,874)$ & 0.000 \\
Chi-square & 987.312 & 174 & 0.000 \\
\hline
\end{tabular}

\subsubsection{Hausman Test}

Once the type of data has been determined, it is now clear which model should be used Fixed effects model or random effects model. In this study, the Hausman test was used to determine the type of model. If the null hypothesis of this test is rejected, the fixed effects model should be used, otherwise the random effects model should be used. Based on the results in Table 4, the null hypothesis is rejected. Therefore, the fixed effects model should be used to estimate the model.

Table 4. Hausman test for the research model.

\begin{tabular}{llll}
\hline Test & Statistic & d.f. & Prob. \\
\hline Chi-square & 13.746 & 5 & 0.049 \\
\hline
\end{tabular}

\subsubsection{Test of Homoscedastic of Likelihood Ratio}

Homoscedastic is a phenomenon in which the variance of disruption components changes over time or between sections. The existence of variance heterogeneity in the model results in estimates that, despite being consistent, are inefficient. Therefore, to ensure that there is no homogeneity variance problem, an homogeneity variance test should be performed. In this study, the likelihood ratio test was used to investigate the presence or absence of heterogeneity variance. The null hypothesis of this test is the homogeneity variance. Therefore, if the null hypothesis is rejected, it means that there is heterogeneity in the research model. In such circumstances, the GLS method should be used.

Based on the results in Table 5, the null hypothesis of the homogeneity variance test is rejected, meaning that the research model faces the problem of heterogeneity variance.

Table 5. Homoscedastic test for the research model.

\begin{tabular}{llll}
\hline Test & Statistic & d.f. & Prob. \\
\hline likelihood ratio & 317.031 & 174 & 0.000 \\
\hline
\end{tabular}

\subsubsection{Wooldridge Test for Autocorrelation}

Another test to be taken in panel models is the autocorrelation test. In this study, Wooldridge autocorrelation test was used. The null hypothesis of this test is the absence of autocorrelation with the disorder. If this assumption is rejected, the research model should estimate the model with AR (1). Based on the results of Table 6, the null hypothesis of the Wooldridge test has not been rejected, meaning that the research model has not encountered any autocorrelation problem.

Table 6. Wooldridge test for research model.

\begin{tabular}{llll}
\hline Test & Statistic & d.f. & Prob. \\
\hline Wooldridge & 0.038 & 174 & 0.823 \\
\hline
\end{tabular}

\subsubsection{Research Model Estimation}

According to the results, Doing Business has the greatest impact on corporate profitability. The estimated coefficient for the Doing Business is 0.2071, which is significant at $99 \%$ level.
This means that with a $1 \%$ increase in Doing Business, corporate profitability increase by $0.2071 \%$. The estimated coefficient for Happiness is 0.1634 which is significant at $99 \%$ level. This means that with a $1 \%$ increase in Happiness, corporate profitability will increase by $0.1634 \%$.

At the end of Table 7, the coefficient of determination, the adjusted coefficient and the Durbin-Watson statistic are presented. The coefficient of determination is 0.973 , indicating that the independent variables were able to explain $97.3 \%$ of the dependent variable changes. Also the adjusted coefficient of determination is 0.969 which due to the small difference of this coefficient with the coefficient of determination it can be said that there is no surplus variable model and the model is well fitted. Durbin-Watson statistic is also 1.657 , so there is no correlation between the residuals.

Table 7. Estimation of Research Model.

\begin{tabular}{lllll}
\hline Var. & Coefficient & Std.error & t-Statistic & Prob. \\
\hline $\ln \mathrm{DB}$ & 0.2071 & 0.0042 & 49.309 & 0.0000 \\
$\ln \mathrm{H}$ & 0.1634 & 0.0127 & 12.866 & 0.0000 \\
$\mathrm{C}$ & -0.3452 & 0.5712 & -0.6043 & 0.0008 \\
$\mathrm{R}^{2}=0.973$ & & $\mathrm{R}_{\text {adjusted }}^{2}=0.969$ & $\mathrm{D} . \mathrm{W}=1.657$ \\
\hline
\end{tabular}

\section{Discussion}

Hypothesis 1: The Business environment index has a positive relationship with the corporate profitability.

According to the results of this study, the Business environment index has a significant positive effect on the corporate profitability. The estimated coefficient is 0.2071 which is significant at $99 \%$ level. Generally, businesses operate in foreign markets for economic reasons. In some cases, businesses may engage in cross-border trade activities due to political factors or policies and practices of governments. Businesses can be found in international activities in different ways. For example, export-import, foreign direct investment, partnership with foreign companies, etc. Ruigrok and Wagner (2003) found that there was a significant relationship between foreign trade and corporate profitability. On the other hand, according to De Soto's [9] research, the administrative system is a major contributor to the problems in developing countries and their desire for underground, informal and unproductive economies. While reducing administrative barriers that are one of the factors contributing to the improvement of the business environment, entrepreneurship development and poverty reduction can be helped. Also, According to Ghosh $\&$ Moon [16] research, one of the factors affecting the quality of profitability is debt financing. That is, getting credit has a significant relationship with profitability. The business environment has a positive and significant relationship on the financial performance of world's top companies (Khazaei, [21]). Therefore, this hypothesis is confirmed.

Hypothesis 2: The Happiness index has a positive relationship with the corporate profitability.

According to the results of this study, The Happiness index has a significant positive effect on the corporate profitability. 
The estimated coefficient is 0.1634 which is significant at $99 \%$ level. A growing number of companies claim to place a high priority on the wellbeing of their workers - and there is a fastgrowing industry of firms selling products related to employee wellbeing. But does investing in employee wellbeing actually lead to higher productivity and are there any tangible benefits to the business bottom line? Experimental evidence such as Oswald et al [24] suggests that the answer is yes. Wright and Staw [32] find a significant and sizeable effect of long term happiness on productivity. More specifically, Boehm and Lyubomirsky [6] preliminarily define a happy person as someone who frequently experiences positive emotions like joy, satisfaction, contentment, enthusiasm and interest. Then, by drawing on both longitudinal and experimental studies, they show that people of this kind are more likely to be successful in their careers. Therefore, this hypothesis is confirmed.

\section{Conclusion}

Business and investment in any area requires the provision of an appropriate and secure institutional environment. Capital owners will invest their capital where signs of economic security are well visible. Policymakers and planners in each region must continually measure and control the state of economic security and investment in that region and, based on the results of these measurements, make arrangements for attracting foreign capital, and prevent the escape of domestic capital. The performance and activity of businesses are influenced by many factors that can be classified into two general categories. The first category is the factors that are in the dominance of firms so that their performance and efficiency are directly measured by them. Another category of factors is outside of the will of the firm, in which case the managers and owners of the firms cannot modify or improve these factors. In the economic literature, some of these factors, whose improvement facilitates production and employment, are known as the "business environment". Happiness is an emotional state characterized by feelings of joy, satisfaction, contentment, and fulfillment. While happiness has many different definitions, it is often described as involving positive emotions and life satisfaction. In this study, we showed that the more suitable the conditions of the business environment and the parameters of happiness in a society, the closer to the ideal conditions, Employee performance and corporate profitability will increase.

\section{Limitations and Research Suggestions}

1. In this study, the impact of business environment and happiness indicators on corporate profitability is studied. Future research can examine the impact of these indices on the non-financial performance companies.

2. China is not very good at business environment and happiness indicators, but between 2013 and 2018, about 11 percent of the world's top 175 companies were profitable in the survey. Therefore, future research can examine the reasons for this.
3. In this study we had no choice but to focus on corporate financial performance, but the most comprehensive study is to examine other functions including internal processes, employee growth and learning and customer attention in future research.

\section{References}

[1] Amabile, Teresa M., Barsade, Sigal G., Mueller, Jennifer S., and Staw, Barry M. 2005. Affect and creativity at work. Administrative Science Quarterly 50: 367-403.

[2] Audretsch, D. B., Lehmann, E. E., Paleari, S. and Vismara, S. (2014). Entrepreneurial finance and technology transfer. J Technol Transf, 41.

[3] Bah, E. \& Fang, L. (2015). Impact of the business environment on output and productivity in Africa. Journal of Development Economics, 114, 159-171.

[4] Becker, B. E., Huselid, M. A., \& Ulrich, D. (2001). The HR Scorecard: Linking People, Strategy and Performance. Boston, MA: Harvard Business School Press.

[5] Besley, T. (2015). Law, Regulation, \& the Business Climate: The Nature and Influence of the World Bank Doing Business Project. Journal of Economic Perspectives, 29 (3).

[6] Boehm, J. K., Lyubomirsky, S. 2008. Does happiness promote career success? Journal of Career Assessment 16, 101-116.

[7] Camison, C., \& Villar-Lopez, A. (2014). Organizational innovation as an enabler of technological innovation capabilities and firm performance. Journal of Business Research, 67 (1), 2891-2902.

[8] Chorev, S., \& Anderson, A. R, (2006). Success in Israeli HighTech Start-Ups; Critical Factors and Process, Technovation 26 (2).

[9] De Soto, H. (1989). The Other Path: The Invisible Revolution in the Third World. New York: Harper and Row.

[10] Doing Business. (2018). A World Bank Group Flagship Report.

[11] Dyck, A. (2000). Privatization and Corporate Governance: Principles, Evidence and Future Challenges, Harvard Business School, Boston., 16 (1), 42-46.

[12] Easterlin, R. (1974). "Does Economic Growth Improve the Human Lot? Some Empirical Evidence", in Nations and Households in Economic Growth: Essays in Honour of Moses Abramowitz, edited by P. A. David and M. W. Reder, Academic Press, New York and London.

[13] Easterlin, R. (1995). "Will Raising the Incomes of All Increase the Happiness of All?", Journal of Economic Behaviour and Organization, 27, 35-48.

[14] Easterlin, R. et al. (2011). The happiness - Income Paradox Revisited. Retrieved from www.Econstor.Eu.

[15] Frank, R. H. (1985). Choosing the Right Pond, Oxford University Press, New York and Oxford.

[16] Ghosh. A. \& Moon, D. (2010). Corporate Debt Financing and Earning Quality, Journal of Business Finance \& accounting, 37, 538-559. 
[17] Gneezy, U. and Rustichini, A. (2000). Pay enough or don't pay at all. The Quartery Journal of Economics, 115 (3): 791-810.

[18] Gujarati, D. (1995). Basic econometrics. $3^{\text {rd }}$ edition.

[19] Hans, M. and Tarasofsky, A. (1997) "Measuring Sustainable Economic Welfare: Looking Beyond GDP" paper presented at the annual meeting of the Canadian Economics Association, St John's, Newfoundland, June 2-4 (available on line at www.csls.ca).

[20] Hirsch, F. (1976). The Social Limits of Growth, Harvard University Press, Cambridge, Mass.

[21] Khazaei, M. (2020). Relationship of profitability of world's top companies with Entrepreneurship, Competitiveness, and Business environment indicators. Applied Economics.

[22] Lan, S., Gao, X., Wang, Q., \& Zhang, Y. (2018). Public Policy Environment and Entrepreneurial Activities: Evidence from China. China \& World Economy, 26 (3), 88-108.

[23] Nordhaus, W. D. and J. Tobin (1972). Is Growth Obsolete?, In: Economic Growth, National Bureau of Economic Research, General Series No. 96, New York, pp. 1-80.

[24] Oswald, A. J., Proto, E., and Sgroi, D. (2015). Happiness and productivity. Journal of Labor economics, 33 (4): 789-822.

[25] Parsons, T. (1960). Structure and Process in Modern Societies. American Journal of Sociology, 66 (5).

[26] Sandeep, V. \& Harpreet, S. B. (2016). Are subjective business performance measures justified? International Journal of Productivity and Performance Management, 65 (5), 603-621.

[27] Sanna, Lawrence J., Turley, Kandi J., and Mark, Melvin M. 1996. Expected evaluation, goals, and performance: Mood as input. Personality and Social Psychology Bulletin 22: 323-325.
[28] Scitovsky, T. (1976). The Joyless Economy, Oxford University Press, Oxford.

[29] Simon, A; Bartle, C; Stockport, G; Smith, B; Jane E. Klobas, E, J \& Sohal, A. (2015). Business leaders' views on the importance of strategic and dynamic capabilities for successful financial and non-financial business performance, International Journal of Productivity and Performance Management, 64 (7), 908-931.

[30] Teng, G., \& Lingyi, H. (2011). Economic Determinants of Happiness: Evidence from the US General Social Survey Economic Determinants of Happiness. Retrieved from https://arxiv.org/abs.

[31] United Nations Industrial Development Organization or Unido (2008). Creating an enabling environment for private sector development in sub-Saharan Africa, Vienna, p. 5. www.unido.org.

[32] Wright, T. A., Staw, B. A. 1998. Affect and favorable work outcomes: two longitudinal tests of the happy-productive worker thesis. Journal of Organizational Behavior, 20, 1-23.

[33] Wu, D. (2009). Measuring performance in small and medium enterprises in the information and communication technology industries, Unpublished $\mathrm{PhD}$ thesis submitted to School of Management College of Business, RMIT University.

[34] Zahra, S. (1993). Environment, Corporate entrepreneurship and financial performance: A taxonomic approach. Journal of Business Venturing, 8 (4).

[35] Zhang, C., (2017). Top manager characteristics, agglomeration economies and firm performance. Small Bus Econ, 48, 543-558. 